\title{
The Role of IL-23 in Patients with Idiopathic Thrombocytopenic Purpura
}

\author{
Zeinab.M .Diab, Shereen.P.Aziz, Heba A. Ahmed, Omnia.S.Fathy
}

\begin{abstract}
Idiopathic thrombocytopenic purpura (ITP)is a bleeding disorder with an unclear etiology ,The most common hemorrhagic autoimmune disease, and characterized by isolated thrombocytopenia that is not accompanied by any other disorders that may lead to thrombocytopenia. Interleukin-23 (IL-23) is a member of the IL-12 family; it is primarily secreted by activated dendritic cells, Monocytes, and macrophages and has important implication in the pathogenesis of many autoimmune diseases. The aims of this study was to evaluate the role of IL-23 in diagnosis of idiopathic thrombocytopenic purpura. A total of 5 papers were obtained using the mentioned keywords in the research of all internetbased databases. The total number of cases in all of the studies was 239 cases. The mean age was recorded in 5 papers, and the mean age of each of them was 32.8 years. There are different method of detection of IL23 in different studies such as PCR, ELISA and flow cytometry These findings suggest that levels of IL-23 are significantly higher in ITP patients.
\end{abstract}

\section{Introduction}

Immune thrombocytopenia(ITP) is autoimmune destruction of platelets in addition to suppression of platelet production by the bone marrow (BM) megakerocytes (Neunert,2013). The cellular immunity deficiency plays an important role in the pathogenesis of ITP, including B-cell activation ,T-cell related disorders and antigen-presenting cell functional defect (Semple JW, et al, 2010)Significantly, it is well-recognized that an abnormal T-cell-mediated response is strongly correlated to the development and progress in ITP (Semple JW, et al, 2012 ). Interleukin 23 (IL- 23 ), which is mainly secreted by antigen-presenting cells, is a member of the IL-12 family, which includes IL-12, IL-27, and IL-35(Gee K, et al ,2009).IL23 is a heterodimeric cytokine, composed of a p19 subunit and a p40 subunit ;it binds IL-23R and IL12R $\beta 1$, the latter being shared with IL12 (Suzuki et al.,2014).The p40 subunit can act as amonomer, homodimer or as a heterodimer with p19 , and both subunits are secreted predominantly by macrophages and dendritic cells (DCs) (Suzuki et al.,2014 and Oppmann et al.,2009)

IL-23 is implicated in the pathophysiology of various autoimmune diseases, such as autoimmune arthritis(Lubberts E, et al, 2008), primary biliary cirrhosis(Qian $\mathbf{C}$, et al, 2013), and inflammatory bowel disease (Fransen K, et al, 2014)

\section{Objectives:}

This study is designed to review the role of IL-23 in diagnosis of idiopathic thrombocytopenic purpura .

\section{Strategy and methods}

The strategy of this systematic review will be based upon raising some research questions addressing the different techniques of role of IL23 in ITP and put a plan to find the best available answers for each. This will be done by looking in 
SOHAG MEDICAL JOURNAL

Vol. 21 No.3 october 2017
The Role of IL-23 in Patients with Idiopathic

Omnia Safwat Fathy.et al the literature and critically appraising the available researches in this field. Good quality researches will be selected to reach a conclusive answer for each question.

\section{The research questions are:}

1-

s there an evidence-based value of IL 23 in diagnosis of ITP?

2-

s there any evidence of dexamethasone in the level of IL23 before and after treatment?

e) The topic of interest: role of IL23 in diagnosis of ITP
3-

ow can we detect the level of IL23 ?

Selection criteria of the available researches:

a) Type of study: systematic review.

b) Time of studies: studies had been published during the last five yehrs from first of January 2012 to 31 December 2016

C) Sites visited:Cochrane I library, PubMed, Medline, Science direct, any other site containing useful information

b) Key words used: Interleukin 23, Idiopathic thrombocytopenic purpura

\section{Results}

A total of 5 papers were obtained using th mentioned keywords in the research of all internetbased databases.

Table 1. Clinical characteristics of acute ITP patients.

\begin{tabular}{|c|c|c|c|c|c|c|c|c|c|c|}
\hline Serial & Author & $\begin{array}{l}\text { Mea } \\
\text { rang }\end{array}$ & & Ge & $\begin{array}{l}\text { der } \\
\text { M }\end{array}$ & $\begin{array}{l}\text { ITP } \\
\text { Mea } \\
\text { rang }\end{array}$ & Iration & $\begin{array}{l}\text { Plt }(x 1 \\
\text { Mean } \\
\text { range }\end{array}$ & & $\begin{array}{l}\text { Bleeding } \\
\text { symptoms }\end{array}$ \\
\hline 1 & $\begin{array}{l}\text { Qingshen Li } \\
\text {,et al }\end{array}$ & 32.5 & $\begin{array}{l}\text { (18- } \\
68)\end{array}$ & $63.6 \%$ & $36.3 \%$ & 5 & $\begin{array}{l}\text { (2-11) } \\
\text { month }\end{array}$ & 11.5 & $(1-31)$ & PT,EC,EP,GUH,GH \\
\hline 2 & Ye X, et al & 36 & $(9-62)$ & $60 \%$ & $40 \%$ & 19.4 & $(1-41) \mathrm{m}$ & 13.3 & $(4-27)$ & PT,EC,EP,GUH,GH \\
\hline 3 & $\begin{array}{l}\text { Hala } \\
\text { M.Farawelaa, } \\
\text { et al }\end{array}$ & 6.29 & $(2-13)$ & $42.9 \%$ & $57.1 \%$ & 7.5 & (3-12)m & 31.79 & $(5-87)$ & PT,EC,EP,GUH,GH \\
\hline
\end{tabular}

Key EC, ecchymoses; EP, epistaxis; GH, gingival hemorrhage; GUH, genitourinary hemorrhage; PT, Petechiae.;

M Male;F,Female ;plt,platelets; ITP, immune thrombocytopenia . 
SOHAG MEDICAL JOURNAL
The Role of IL-23 in Patients with Idiopathic Omnia Safwat Fathy

Table 2. Clinical characteristics of chronic ITP patients.

\begin{tabular}{|c|c|c|c|c|c|c|c|c|c|c|}
\hline \multirow{2}{*}{$\begin{array}{l}\text { Serial } \\
\\
1\end{array}$} & \multirow{2}{*}{$\begin{array}{l}\text { Author } \\
\\
\begin{array}{l}\text { Qingshen Li } \\
\text {,et al(2014) }\end{array}\end{array}$} & \multicolumn{2}{|c|}{$\begin{array}{l}\text { Age } \\
\text { Mean } \\
\text { range }\end{array}$} & $\mathbf{F}$ & der & \multicolumn{2}{|c|}{$\begin{array}{l}\text { ITP } \\
\text { duration } \\
\text { Mean } \\
\text { range }\end{array}$} & \multicolumn{2}{|c|}{$\begin{array}{l}\operatorname{Plt}\left(\mathbf{x 1 0}^{9} \Lambda \mathbf{L}\right) \\
\text { Mean } \\
\text { range }\end{array}$} & \multirow{2}{*}{$\begin{array}{l}\text { Bleeding } \\
\text { symptoms } \\
\text { PT,EC,EP,GUH,GH }\end{array}$} \\
\hline & & 36.5 & $\begin{array}{l}\text { (17- } \\
\text { 72) }\end{array}$ & $62.5 \%$ & $37.5 \%$ & 66 & $\begin{array}{l}(12- \\
252) m\end{array}$ & 12.5 & $\begin{array}{l}\text { (3- } \\
47)\end{array}$ & \\
\hline 2 & $\begin{array}{l}\text { Qingshen Li } \\
\text {,et al(2015) }\end{array}$ & 39 & $\begin{array}{l}(17- \\
72)\end{array}$ & $65.7 \%$ & $34.2 \%$ & 5 & $\begin{array}{l}(1- \\
21) m\end{array}$ & 11 & $\begin{array}{l}(2- \\
47)\end{array}$ & PT,EC,EP,GUH,GH \\
\hline 3 & $\begin{array}{l}\text { Hala } \\
\text { M.Farawelaa, } \\
\text { et al(2016) }\end{array}$ & 7.9 & $\begin{array}{l}\text { (2- } \\
14)\end{array}$ & $50 \%$ & $50 \%$ & & $>12 m$ & 124.14 & $\begin{array}{l}(55- \\
216)\end{array}$ & PT,EC,EP,GUH,GH \\
\hline
\end{tabular}

Key EC, ecchymoses; EP, epistaxis; GH, gingival hemorrhage; GUH, genitourinary hemorrhage; PT, Petechiae.;

M Male;F,Female ;plt,platelets; ITP, immune thrombocytopenia .

Table 3. effect of dexamethasone on platelet count.

\begin{tabular}{|c|c|c|c|c|c|c|c|c|}
\hline \multirow{3}{*}{$\begin{array}{l}\text { Serial } \\
\\
1\end{array}$} & \multirow{3}{*}{$\begin{array}{l}\text { Author } \\
\text { Yanxia Zhan, } \\
\text { etal }\end{array}$} & \multirow{3}{*}{\begin{tabular}{|l|} 
year \\
2013
\end{tabular}} & \multicolumn{2}{|c|}{$\begin{array}{c}\text { Number of } \\
\text { cases }\end{array}$} & \multicolumn{2}{|c|}{$\begin{array}{l}\text { Plt count before } \\
\text { DXM }\end{array}$} & \multicolumn{2}{|c|}{ Plt count after $\mathrm{DXM}$} \\
\hline & & & $\mathbf{F}$ & $\mathbf{M}$ & Mear & range & & \\
\hline & & & 40 & 10 & 6 & $(1-19)$ & 198 & (101-289) \\
\hline 2 & $\begin{array}{l}\text { Qingshen Li ,et } \\
\text { al }\end{array}$ & 2015 & 25 & 13 & 11 & $(2-47)$ & 125 & $(13-231)$ \\
\hline 3 & Ye X, et al & 2015 & 7 & 4 & 13.8 & $(7-22)$ & 119 & $(37-257)$ \\
\hline
\end{tabular}

KEY M Male;F,Female ;plt,platelets ; DXM ,Dexamethasone . 
Table 4.correlation between level of IL23 and dexamethasone

\begin{tabular}{|c|c|c|c|c|}
\hline Serial & Author & year & Number of cases & Level of IL23 after dexamethasone \\
\hline 1 & Yanxia Zhan, etal & 2013 & 54 & $\begin{array}{l}\text { our SNPs in the IL-23R gene were not } \\
\text { shown to have relationship with } \\
\text { prognostication of the therapeutic response } \\
\text { of HD-DXM (p all >0.05). } \\
\text { hese results suggested that IL-23R } \\
\text { polymorphisms may not serve as predictors } \\
\text { of response to HD-DXM. }\end{array}$ \\
\hline 2 & Qingshen Li ,et al & 2015 & 38 & $\begin{array}{l}\text { - } \\
\text { he plasma level of IL-23 } \\
\text { in patients had decreased significantly } \\
\text { after treatment }(p<0.01) \text { and normalized } \\
\text { after HD-DXM treatment } \\
\text { - } \\
\text { he plasma level of IL-23 ( } \mathrm{r}=0.567, \mathrm{p}< \\
0.001) \text { was negatively correlated with the } \\
\text { platelet counts in the c ITP patients after } \\
\text { treatment } \\
\text { here were no significant differences in the } \\
\text { plasma level of il23 between the patients } \\
\text { with a complete response and the normal } \\
\text { controls (p > } 0.05) \text {. } \\
\text { However, the level of, IL-23 } \\
\text { was still significantly higher in patients } \\
\text { with no response than in normal controls. }\end{array}$ \\
\hline 3 & Ye X, et al & 2015 & 11 & $\begin{array}{l}\text { Decreased plasma level of IL-23 after } \\
\text { effective treatment }\end{array}$ \\
\hline
\end{tabular}


SOHAG MEDICAL JOURNAL

Vol. 21 No.3 october 2017
The Role of IL-23 in Patients with Idiopathic

Omnia Safwat Fathy

Table 5.correlation between level of IL23 and platelet count before treatment with dexamethasone

\begin{tabular}{|l|l|l|l|}
\hline Serial & Author & year & correlation between level of IL23 and platelet count \\
\hline 1 & Qingshen Li ,et al & 2014 & $\begin{array}{l}\text { The PB plasma level of IL-23 was negative correlated } \\
\text { with platelet counts in ITP patients (IL-23: } \mathbf{r}=\mathbf{0 . 3 2 7 ,} \\
\mathbf{p}=\mathbf{0 . 0 2 7})\end{array}$ \\
\hline $\mathbf{2}$ & Ye X, et al & $\mathbf{2 0 1 5}$ & $\begin{array}{l}\text { IL-23 level in ITP plasma was negative correlated with } \\
\text { platelet count }\end{array}$ \\
\hline
\end{tabular}

Table 6. method of detection of IL23 in different study.

\begin{tabular}{|c|c|c|c|}
\hline Serial & Author & Year & method \\
\hline 1 & Yanxia Zhan, etal & 2013 & PCR \\
\hline 2 & Qingshen Li ,et al & 2014 & $\begin{array}{l}\text { CR } \\
\bullet \\
\text { lowcytometry }\end{array}$ \\
\hline 3 & Qingsheng Li ,et al & 2015 & $\begin{array}{l}\bullet \\
\text { LISA } \\
\bullet \\
\text { lowcytometry }\end{array}$ \\
\hline 4 & Ye X, et al & 2015 & $\begin{array}{l}\bullet \\
\text { CR } \\
\bullet \\
\text { LISA } \\
\text { lowcytometry }\end{array}$ \\
\hline 5 & Hala M.Farawelaa, et al & 2016 & PCR \\
\hline
\end{tabular}

Key PCR, Polymerase chain reaction ;ELIZA, Enzyme-Linked Immunosorbent Assays .

\section{Discussion}

The aims of this study was to evaluate the role of IL-23 in diagnosis of Idiopathic thrombocytopenic purpura. A total of 5 papers were obtained using the mentioned keywords in the research of all internet-based

databases. The total number of cases in all of the studies

was 239 cases. The Clinical characteristics of acute In patients in different studies show that there are more common in female ,( Qingshen $\mathbf{L i}$ 
,et al 2014, Ye X, et al 2015) but one paper find that there are more common in male (Hala M.Farawelaa, et al 2016), and ITP duration takes about(141) month, platelet count ranged from

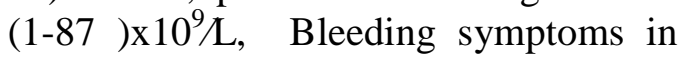
acute ITP patients (petechiae, ecchymoses ,epistaxis ,gentiourinary haemorrhage, gingival haemorrhage). The Clinical characteristics of chronic ITP patients in different studies show that there are more common in female, Qingshen Li ,et al 2014, Qingshen Li ,et al 2015) but one paper find that there are equal in both male and female(Hala M.Farawelaa, et al 2016), ), and ITP duration take about(1-252) month, platelet count ranged from (2-216 ) $10^{9} \mathrm{~L}$, Bleeding symptoms in chronic ITP patients (petechiae, ecchymoses ,epistaxis ,gentiourinary haemorrhage, gingival haemorrhage). There are different methods of detection of IL23 in different study such as PCR (Yanxia Zhan, etal 2013, Qingshen $\mathrm{Li}$,et al 2014, Ye $X$, et al 2015, Hala M.Farawelaa, et al 2016),ELISA (Qingsheng Li ,et al 2015 Ye X , et al 2015),flow cytometry(Qingshen Li ,et al 2014, Ye $X$, et al 2015). Studies which detect IL 23 by PCR provide that that IL-23R rs1884444 could influence ITP susceptibility but do not predict the therapeutic response ofHD-DXM . However, there are some limitations in this study, such as small size of the cohort. Thus, further investigations incorporating diverse population and more subjects are warranted to validate and expand our findings. (Yanxia Zhan, etal 2013), In other study provide that IL-23R rs1884444 SNP plays no role in PIT susceptibility in pediatric Egyptian population Therefore, we recommend to perform the study on a larger cohort of patients to gain greater insight into potential effects of the IL-23Rrs1884444 gene polymorphisms on the development and prognosis of PIT and also to determine their pathogenetic implications. Studying polymorphisms other than IL-23R rs1884444 SNP could open new gates for understanding the pathogenesis of PIT and hence facilitate the exploration of new therapeutic modalities. Moreover, additional studies in patients with PIT of different populations and age groups are needed to better understand the factors contributing to the occurrence of PIT. (Hala M.Farawelaa, et al 2016), In other study documented a significant up regulation of IL-23 at mRNA and protein levels in $\mathrm{BM}$ as well as in $\mathrm{PB}$ of patients with ITP These results suggested that up-regulated IL-23 may be responsible for the immune responses of ITP and reflected the importance of the Th1 and Th17 cytokines milieu in the immunopathogenesis of ITP. Modulation of IL-23 might provide therapeutic benefits for IT ( Qingshen $\mathbf{L i}$,et al 2014). IL-23 p19and p40 and IL-23R mRNA expression were both significantly increased in ITP patients, There was no statistical difference in these measures between newly diagnosis group and re-activated group. (Ye $\mathbf{X}$, et al, et al 2015), Studies which detect IL23 by ELISA provide that the plasma levels of , IL-23, were significantly higher in c ITP patients than those in the controls before HD-DXM treatment (Qingsheng Li ,et al 2015), the IL-23 and IL-17 level in plasma from ITP patients were both significantly increased. We did not observed any statistical difference in plasma IL-23 and IL-17 levels between newly diagnosis group and re-activated group (Ye $\mathbf{X}$, et al, et al 2015)

Studies which detect IL23 by flow cytometry provide that the plasma levels of , IL-23, were 
significantly higher in ITP patients (Qingshen Li ,et al2014, Ye X, et al 2015)

The plasma level of IL-23 in patients had decreased significantly after HDDXMtreatment (Qingshen Li ,et al2014, Ye $X$, et al 2015) but Four SNPs in the IL-23R gene were not shown to have relationship with prognostication of the therapeutic response of HD-DXM. (Yanxia Zhan, etal 2013)

Effect of dexamethasone on platelet count in patients with ITP, show increase in count after treatment, platelet count before treatment (147) $x 109 /$ and after treatment (13 - 289) $\mathrm{x} 109 / \mathrm{L}$. plasma level of IL-23 was negative correlated with platelet count. These findings suggest that levels of IL-23 are significantly higher in ITP patients.

Conclusion

In conclusion, the results of our research suggest that the levels IL-23 are significantly higher in ITP patients.

\section{References}

1.

1. ransen K, van Sommeren S, Westra HJ, Veenstra M, Lamberts LE, et al. (2014) Correlation of genetic risk and messenger RNA expression in a Th17/IL23 pathway analysis in inflammatory bowel disease.Inflamm Bowel Dis 20: 777-782. Doi:10.1097

2. Gee K, Guzzo C, Che Mat NF, Ma W, Kumar A (2009) The IL-12 family of cytokines in infection, inflammation and autoimmune disorders. Inflamm Allergy Drug Targets 8: 40-52. PMID: 19275692

3.Hala M. Farawela, Shahira K.A. Botros, Mona El-Ghamrawy and Eman O. Ebrahim,(2015) Blood Coagulation and Fibrinolysis 2016, 27:374-377.

4. Lubberts E (2008) IL-17/Th17 targeting: on the road to prevent chronic destructive arthritis Cytokine 41: 84-91. PMID: 18039580

5.Neunert CE (2013):Current management of immune thrombocytopenia. ASH Education book,2013(1) 276-282.

6.Oppmann B, Lesley R, Blom B, et al(2009): Novel p19 protein engages IL-12p40 to form a cytokine, IL-23, with biological activities similar as well as distinct from IL-12. Immunity ;13:715-25
7.Qian C, Jiang T, Zhang W, Ren C, Wang Q, et al. (2013) Increased IL-23 and IL-17 expression by peripheral blood cells of patients with primary biliary cirrhosis. Cytokine 64: 172-180. doi: 10.1016/j.cyto.2013.07.005 PMID: 23910013

8.Qingsheng Li a Linjie Zhang b Ruixiang Xia a Qingshu Zeng a Yongqing Wang a Liang Xia a Leiming Xia a Mingzhen Yang(2014) Med Princ Pract DOI: 10.1159/000433472.

9.Qingsheng Li, Mingzhen Yang , Ruixiang Xia, Leiming Xia, \& Linjie Zhang (2014 )Informa UK Ltd. DOI: 10.3109/09537104.2014.934217

10.Semple JW, Provan D (2012) The immunopathogenesis of immune thrombocytopenia: $\mathrm{T}$ cells still takecenterstage. Curr Opin Hematol 19: 357-362. doi:10.1097/MOH.0b013e3283567541 PMID:22759631.

11.Semple JW, Provan D, Garvey MB, Freedman $\mathbf{J}$ (2010) Recent progress in understanding the pathogenesisof immune thrombocytopenia. Curr Opin Hematol 17: 590-595.

doi:10.1097/MOH.0b013e32833eaef3 PMID: 20739879

12.Suzuki E, Mellins ED, Gershwin ME, et al (2014): The IL-23/IL-17 axis in psoriatic arthritis. Autoimmun Rev;13(4-5):496-502,

13. Yanxia Zhan \& Fanli Hua \& Lili Ji \& Weiguang Wang \&Shanhua Zou \& Xiaoyun Wang \& Feng Li \&Yunfeng Cheng Ann Hematol (2013) 92:1057-1062 DOI 10.1007/s00277-013-1731-3.

14.Ye X, Zhang L, Wang H, Chen Y, Zhang W,Zhu R, et al. (2015) The Role of IL23/Th17 Pathway in Patients with Primary Immune Thrombocytopenia. PLoS ONE 10(1): e0117704. doi:10.1371/journal.pone.0117704 . 